\title{
AZ INVÁZIÓS TÖLGY CSIPKÉSPOLOSKA [CORYTHUCHA ARCUATA (SAY, 1832)] GYORS TERJESZKEDÉSE ÉS TÖMEGES FELLÉPÉSE MAGYARORSZÁGON
}

\author{
Csepelényi Mariann¹, Hirka Anikó², Szénási Ágnes', Mikó Ágnes², Szőcs Levente² és \\ Csóka György ${ }^{2}$
}

${ }^{1}$ Szent István Egyetem MKK Növényvédelmi Intézet, Gödöllő

${ }^{2}$ NAIK Erdészeti Tudományos Intézet Erdővédelmi Osztály, Mátrafüred

\begin{abstract}
Kivonat
Az észak-amerikai tölgy csipkéspoloskát (Corythucha arcuata) Európában először Észak-Olaszországban észlelték (2000). Magyarországon 2013-ban találták meg, az azóta eltelt öt évben, különösen pedig 2016-ban és 2017-ben gyors terjeszkedést mutatott. 2017 őszéig öt kivételével (Borsod-Abaúj-Zemplén, Nógrád; Győr-Moson-Sopron, Vas és Veszprém) minden magyarországi megyében elökerült. Békés, Csongrád, Jász-Nagykun-Szolnok és Baranya megyei kocsányos tölgyesekben már állományszintü, tömeges fellépését is észleltük, aminek összesített területe a becslések szerint legalább 5000 ha. A következő években további terjedése és tömegszaporodásai várhatóak. A kártevő tömeges fellépése július elejére/közepére jelentős lombsárgulást okoz. Ennek hosszú távú hatásai a tölgyesek növedékére, egészségi állapotára, makktermésére egyelöre nem ismertek. Jelenleg megfelelö védekezési mód sem ismert.
\end{abstract}

Kulcsszavak: inváziós faj, tölgy csipkéspoloska, Corythucha arcuata, terjeszkedés, Quercus.

\section{RAPID AREA EXPANSION AND MASS OCCURRENCES OF THE INVASIVE OAK LACE BUG [CORYTHUCHA ARCUATA (SAY 1932)] IN HUNGARY}

\begin{abstract}
The North American oak lace bug (Corythucha arcuata) was first discovered in Europe in Northern Italy (2000). In 2013, it was found in Hungary. In the last five years, particularly in 2016 and 2017, the species showed rapid area expansion. Until autumn 2017 it has been found in all Hungarian counties except five ones (Borsod-Abaúi-Zemplén, Nógrád; Györ-MosonSopron, Vas and Veszprém). Outbreaks were recorded in several pedunculate oak stands in Békés, Csongrád, JászNagykun-Szolnok and Baranya counties, covering ca. 5,000 hectares of forest area in total. Further spread and outbreaks are expected in the next years. The severe infestation causes mass yellowing of the foliage by early and mid-July, long term consequences of this effect are not yet known. Neither efficient nor environmentally friendly control methods were established by now.
\end{abstract}

Keywords: invasive species, oak lace bug, Corythucha arcuata, area expansion, Quercus. 


\section{BEVEZETÉS}

Európában, így Magyarországon is gyorsuló ütemben jelennek meg fásszárúakon élő idegenhonos rovarfajok (Csóka et al. 2012; Tuba et al. 2012). A megtelepedő idegenhonos rovarfajok némelyike csak lassan terjeszkedik, és nem okoz számottevő ökológiai/ökonómiai károkat. Mások rövidebb-hosszabb látens állapotot követően gyors terjeszkedést és jelentős népességnövekedést mutathatnak. Az utóbb esetre szolgáltat látványos példát a tölgy csipkéspoloska (Corythucha arcuata Say, 1832) - Hemiptera: Tingidae). Jelen közleményben irodalmi adatok alapján áttekintjük eddig ismert eurázsiai előfordulásait, illetve saját adataink alapján bemutatjuk magyarországi elterjedését, illetve terjeszkedését a 2013-2017-es idöszakra vonatkozóan.

\section{A TÖLGY CSIPKÉSPOLOSKA ISMERT EURÓPAI ELŐFORDULÁSAI}

Észak-amerikai faj, Európában először 2000-ben, Észak-Olaszországban észlelték (Bernardinelli 2000; Bernardinelli \& Zandigiacomo 2000), majd két évvel később Törökországban is megtalálták (Mutun 2003). 2002-ben Svájc déli részén rovarcsapdával fogtak két kifejlett példányt, 2004 februárjában, lehullott leveleken pedig már petecsomókat is észleltek (Forster et al. 2005). 2005-ben Iránban (Nyugat-Azerbajdzsán tartomány) is találtak egy példányt (Samin \& Linnavuori 2011). 2008 nyarára Törökországban már jelentős expanziót mutatott, ekkor már 28000 km²-re becsülték elterjedési területét (Mutun et al. 2009). Nagyon valószínű, hogy ez a terület szolgálhatott forrásul a további északi, északnyugati irányú terjeszkedéshez. 2012-ben Bulgáriából (Plovdiv mellől) is előkerült (Dobreva et al. 2013). 2013 májusában Magyarországon a Szarvasi Arborétumban, néhány nappal később pedig a vácrátóti Nemzeti Botanikus Kertben is megtalálták (Csóka et al. 2013). Érdekességként megemlíthető, hogy az előzetes várakozással (Csóka et al. 2010) ellentétben nem az ország délnyugati, hanem délkeleti részén jelent meg elöször. Az ország délnyugati részében csak 2017 nyarán tűnt fel (lásd késöbb). Többek között ez is arra utal, hogy hozzánk nem az olaszországi, hanem a törökországi gócból kiindulva a Balkánon keresztül juthatott el. A magyarországi felfedezéssel közel egy időben észlelték Horvátország keleti felében, Szlavóniában (Hrašovec et al. 2013) és Szerbiában (Glavendekić szóbeli közlés, Poljaković-Pajnik et al. 2015, Glavendekić 2017). 2016-ban már biztosan jelen volt Albániában is (Ejup Cota szóbeli közlés), ugyanakkor Macedóniában még nem találták meg (Irina Papazova szóbeli közlése), holott az ország elhelyezkedéséböl fakadóan ez valószínüsíthető lett volna. Romániában 2015 őszén Arad közelében (Don et al. 2016), 2016 nyarán pedig Bukarestben is megtalálták (Chireceanu et al. 2017). Ugyanezen év őszén Szlovéniában, a horvát határ közelében is elökerült (Jurc \& Jurc 2017). 2016-ban Oroszországban, Krasznodar körzetéből is jelzik, meglepő módon mindjárt 330 ezer ha erősen fertőzött területről (Neimorovets et 
al. 2017). Bosznia-Hercegovinában 2017 nyarán találták meg (Glavendekić \& Vukovic-Bojanović 2017, Dautbašić et al. 2018). Az első észlelést követően minden érintett országban jelen-tős terjeszkedést, több helyütt pedig tömegszaporodásokat regisztráltak. Megjegyzendő, hogy az egyes országokban történt észlelés évszáma nem feltétlenül tükrözi a tényleges megjelenés valós idejét, egyes esetekben sokkal inkább mutatja azt, hogy az egyes or-szágokban mikor kezdték el intenzíven keresni a fajt. Ugyanakkor az eddigi megfigyelések és adatgyüjtések alapján feltételezhető, hogy a tölgy csipkéspoloska passzív terjedését elsősorban a közúti és a vasúti közlekedés segíti elő. Ebböl adódóan terjedése nem egy egyenletesen mozgó „frontvonal” mentén zajlik, hanem kisebb, egymástól távoli gócokban is megjelenhet. Így a terjeszkedés rekonstruálása csupán elöfordulási adatokra alapozva nehéz.

\section{AZ ADATGYŰJTÉS MÓDSZERE}

Az első hazai észlelést (2013. május - Csóka et al. 2013) követően folyamatosan ellenőriztük azokat a tölgyeseket, amiket erdővédelmi monitoring munkánk során éves rendszerességgel felkerestünk, illetve amelyeket útjaink során érintettünk. A tölgy csipkéspoloska jelenlétére utaló kárképek kis gyakorlattal könnyen felismerhetők. llyen jelek pl. a levélfelszín korai, „márványos” elszíneződése (1. ábra), illetve a levélfonákon látható pe-ték, lárvák, kifejlett egyedek és azok ürüléke (2. ábra). Erős fertőzés esetén a tölgyek teljes lombozata elszíneződik (3. ábra).

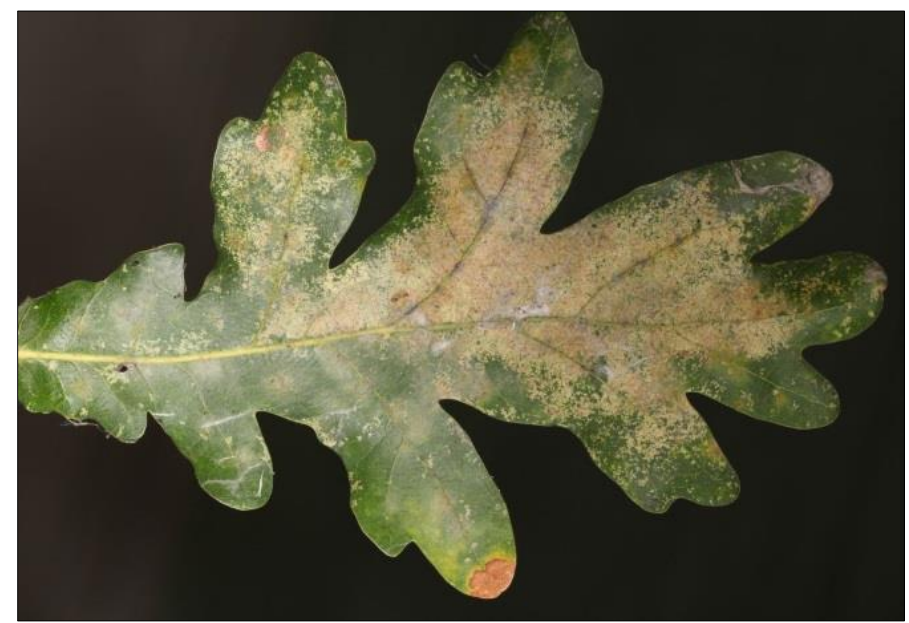

1. ábra: Tipikus „márványos” elszíneződés kocsányos tölgy levélfelszínén.

Figure 1: Typical "mottled" discolouration on the upper side of a pedunculate oak leaf. 

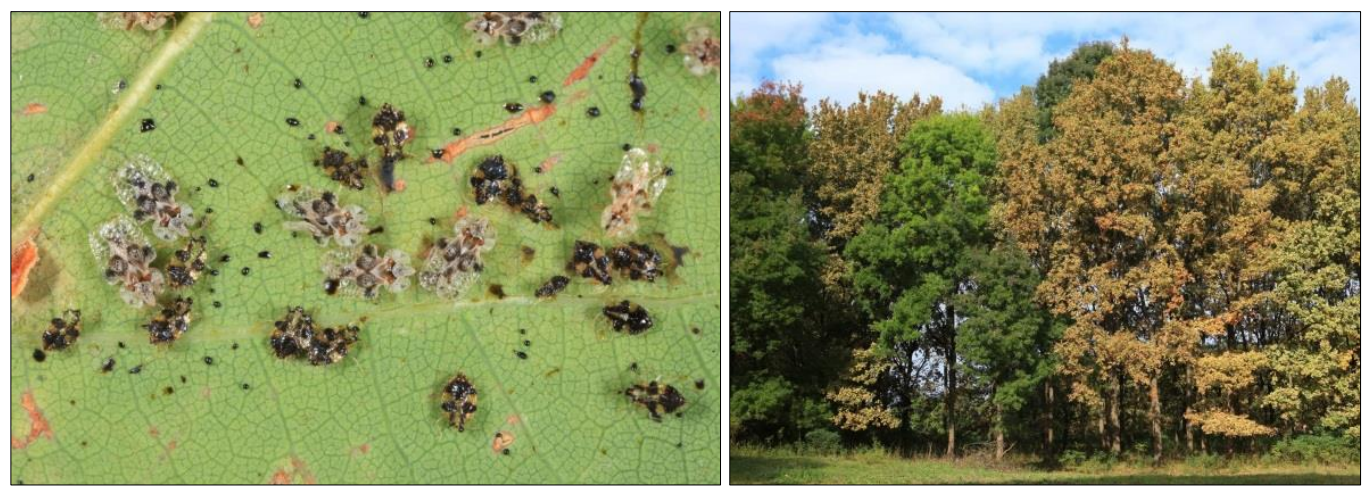

2. ábra (balra): A tölgy csipkéspoloska lárvái és imágói kocsányos tölgy levélfonákján.

Figure 2 (left): Larvae and adults of the oak lace bug on the underside of a pedunculate oak leaf.

3. ábra (jobbra): Erős fertőzés Gyula környéki kocsányos tölgyesben. A zöld lombozatú fák kőrisek. Figure 3 (right): Severe infestation of the oak lace bug in a pedunculate oak stand (vicinity of Gyula -SE Hungary). The green canopies are ashes.

Az új előfordulásokat (GPS koordinátákkal) és tápnövény adatokat, valamint a fertőzöttség mértékét (az alábbi skála alapján) rögzítettük.

1. A tünetek egy-egy levélen, elszórtan láthatók, célirányos kereséssel találhatók meg.

2. A tünetek egy-egy ágon, illetve egyes fákon jelentkeznek, könnyen észrevehetök.

3. A tünetek tömegesek, jellemzően facsoport/állomány szinten jelentkeznek, már nagy távolságból is egyértelműen felismerhetők.

Jelen közleményben csak az eddig ismert elöfordulási adatokat, illetve a 2017-es tömeges fellépések (3-as fokozat) helyszíneit mutatjuk be, Google Earth térképen ábrázolva, éves bontásban. A fertőzöttség mértékére vonatkozó részletes adatok a NAIK ERTI Erdővédelmi Osztályán rendelkezésre állnak. Az erdőállományokban és arborétumokban gyüjtött tápnövény adatokat külön közleményben tervezzük ismertetni.

\section{EREDMÉNYEK ÉS MEGVITATÁSUK}

A 2013-2017 között feljegyzett új előfordulási adatok a tölgy csipkéspoloska egyértelmű nyugati és északi irányú terjeszkedésére utalnak (4. ábra). 2016-ban a terjedés felgyorsult, az év őszére már a Dunától kissé nyugatra is ismertté váltak előfordulásai. 2017-ben délröl és keletröl egyidejüleg tovább terjedve meghódította a Dunántúl déli részét. Jelenleg már csak a Borsod-Abaúj-Zemlén, Nógrád, Györ-Moson-Sopron, Vas és Veszprém megyékböl nincs ismert előfordulási adata. A legészakibb magyarországi előfordulás (Felsőtárkány - 
47,998889; 20,436944) egyben a legészakibb európai adat is. Megjegyzendő azonban, hogy alacsony népességnél meglehetősen nehéz a faj jelenlétének észlelése, így a tényleges megtelepedés valószínüleg az első észlelés előtt már néhány évvel bekövetkezik. Ebböl következően feltételezhető, hogy elszórtan mára már az egész országban elterjedt, de az északnyugati országrészben az alacsony népesség miatt még nem tűnt fel esetleges előfordulása. Várható tehát, hogy 2018-ban a Balatonról északra is „láthatóvá válik”. Erre az eddigi tapasztalatok alapján különösen a forgalmasabb közutak mentén van számottevő esély.
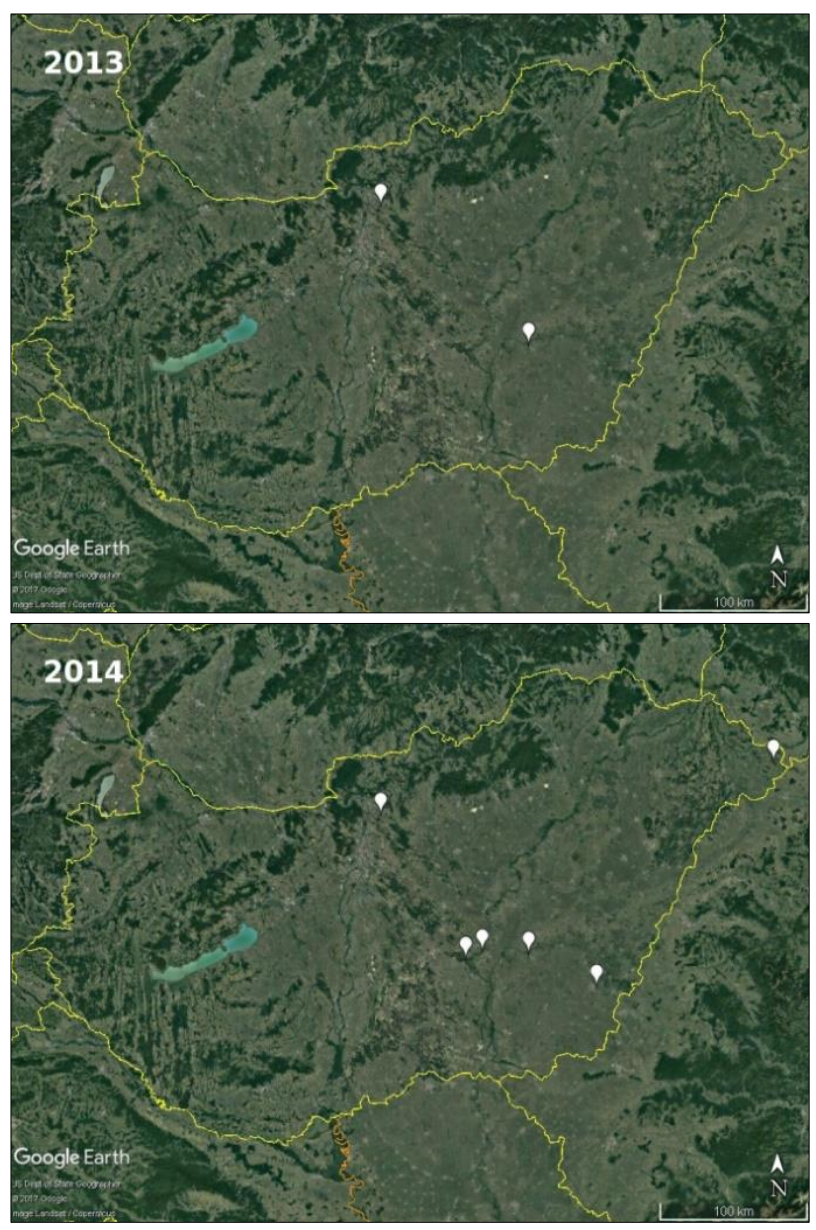

4. ábra: A tölgy csipkéspoloska ismert magyarországi előfordulásai a 2013-2017-es időszakban, évenként. Figure 4: Known records of the oak lace bug in Hungary between 2013 and 2017, by years. 

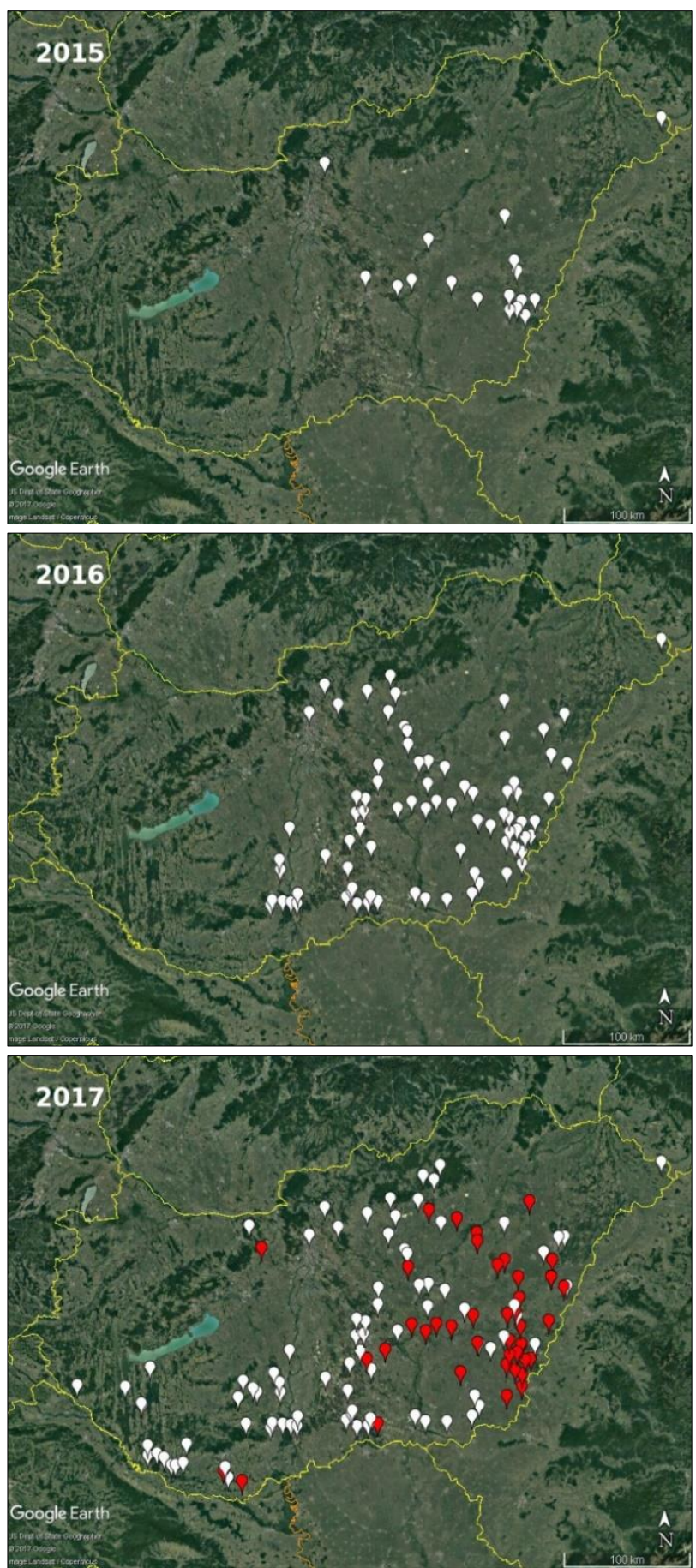

4. ábra (folytatás): A tölgy csipkéspoloska ismert magyarországi előfordulásai a 2013-2017-es időszakban, évenként. Pirossal a 2017-ben észlelt erös fertőzési gócok (3-as fokozat).

Figure 4 (cont.): Known records of the oak lace bug in Hungary between 2013 and 2017, by years. Red markers indicate severe infestations. 
Bár a kifejlett poloskák röpképesek, a faj terjedése valószínüleg elsősorban passzív módon zajlik. Ebben közre játszhat a szél segítségével történő terjedés is, de az eddigi ismeretek alapján a közúti és vasúti forgalom segítségével történő terjedést tartjuk legnagyobb jelentőségűnek. Hazai (Csepelényi et al. 2017) és bulgáriai (Dobreva et al. 2013) megfigyelések alapján elmondható, hogy a faj általában forgalmas utak mentén, autópálya-pihenőkben, városokban tünik fel elöször, és innen terjed tovább a forgalom által kevésbé érintett erdőterületek felé. Ebböl ugyanakkor az is következik, hogy terjedését megfékezni lehetetlen, de még csak lassítani sem igen lehet. Hazánkban a faj háromnemzedékes, azaz egy vegetációs időszakon belül is drámaian növekedhet a népessége. Az abundáns népesség pedig egyaránt növeli a terjedés aktív és passzív módozatainak esélyét.

A magyarországi arborétumokban végzett tápnövény vizsgálatok szerint gyakorlatilag minden eurázsiai lombhullató tölgy megfelelő tápnövénye lehet (Csóka et al. publikálatlan adatai), azaz a tápnövény hiánya nemigen fogja korlátozni további terjeszkedését.

Egyelöre nem tudható, hogy a klimatikus viszonyok hol fognak határt szabni terjeszkedésének, illetve tömeges fellépéseinek. Az azonban tény, hogy a 2016/2017-es, viszonylag hideg tél Gyula és Szarvas körzetében nem okozott jelentős mortalitást a telelö népességben (Csepelényi et al. 2017). Korábbi, hasonló jellegű vizsgálatok hiányában csak feltételezni tudjuk, hogy az enyhe teleknek köszönhető alacsony telelési mortalitásra vezethető vissza, hogy terjeszkedése Európában az utóbbi 4-5 évben gyorsult fel, amiket többségében enyhe, szinte fagymentes telek jellemeztek.

A faj életmódjára, tömeges, „krónikus” jelenlétének rövid és hosszú távú kihatásaira, valamint a lehetséges védekezési módokra vonatkozóan további célirányos kutatások szükségesek.

\section{KÖSZÖNETNYILVÁNÍTÁS}

A tölgycsipkéspoloskával kapcsolatos kutatómunkánkat a VKSZ_12-1-2013-0034-Agrárklíma.2 projekt támogatásával végeztük.

\section{FELHASZNÁLT IRODALOM}

Bernardinelli I. 2000: Distribution of the oak lace bug Corythucha arcuata (Say) in Northern Italy (Heteroptera: Tingidae). Redia 83: 157-162.

Bernardinelli I. \& Zandigiacomo P. 2000: Prima segnalazione di Corythucha arcuata (Say) (Heteroptera, Tingidae) in Europa. Informatore Fitopatologico 50(12): 47-49.

Chireceanu C., Theodoru A. \& Chiriloaie A. 2017: New Records of the Oak Lace Bug Corythucha arcuata (Say, 1832) (Hemiptera: Tingidae) in Southern Romania. Acta Zoologica Bulgarica, Suppl. 9, 2017: 297-299.

Csepelényi M., Hirka A., Mikó Á., Szalai Á. \& Csóka Gy. 2017: A tölgy csipkéspoloska (Corythucha arcuata) 2016/2017-es áttelelése Délkelet-Magyarországon. Növényvédelem 53(7): 285-287. 
Csóka Gy., Hirka A. \& Lakatos F. 2010: Már a spájzban vannak... Növényvédelem 46(11): 547-550.

Csóka Gy., Hirka A. \& Somlyai M. 2013: A tölgy csipkéspoloska (Corythucha arcuata Say, 1832 - Hemiptera, Tingidae) első észlelése Magyarországon. Növényvédelem 49(7): 293-296.

Csóka Gy., Hirka A. \& Szőcs L. 2012: Rovarglobalizáció a magyar erdőkben. Erdészettudományi Közlemények 2: 187-198.

Dautbašić M., Zahirović K., Mujezinović O. \& Margaletić J. 2018: Prvi nalaz hrastove mrezaste stjenice (Corythucha arcuata) u Bosni i Hercegovini. Sumarski list 3-4: in press.

Dobreva M., Simov N., Georgiev G., Mirchev P. \& Georgieva M. 2013: First record of Corythucha arcuata (Say) (Heteroptera: Tingidae) on the Balkan Peninsula. Acta Zoologica Bulgaria 65(3):409-412.

Don I., Don C.D., Sasu L.R., Vidrean D. \& Brad M.L. 2016: Insect pests on the trees and shrubs from the Macea Botanical Garden. Studia Universitatis „Vasile Goldis” Arad 11(2): 23-28.

Forster B., Giacalone I., Moretti M., Dioli P. \& Wermelinger B. 2005: Die amerikanische Eichennetzwanze Corythucha arcuata (Say) (Heteroptera, Tingidae) hat die Südschweiz erreicht. Mitteilungen der Schweizerischen Entomologischen Gesellschaft 78(3-4): 317-323.

Glavendekić M. 2017: Fauna i ekologija insekata koji naseljavaju invazivne i nativne ukrasne biljke u "Ukrasne i invazivne biljke u uslovima klimatskih promena - uticaji i adaptacije", Obratov-Petkovic D. ed., Monografija, Univerzitet u Beogradu-Šumarski fakultet, Beograd, 240-264.

Glavendekić M. \& Vukovic-Bojanović V. 2017: Prvi nalaz hrastove mrežaste stenice Corythucha arcuata (Say) (Hemiptera: Tingidae) u Bosni i Hercegovini i novi nalazi u Srbiji, Zbornik rezimea XI Simpozijum entomologa Srbije, Goč, 17-21.09-2017, Book of Abstracts of XI Symposium of Entomologists of Serbia, Goc, 70 71.

Hrašovec B., Posarić D., Lukić I. \& Pernek M. 2013: Prvi nalaz hrastove mrežaste stjenice (Corythucha arcuata) u Hrvatskoj. Šumarski list 137(9-10): 499-503.

Jurc M. \& Jurc D. 2017: The first record and the beginning the spread of oak lace bug, Corythucha arcuata (Say, 1832) (Heteroptera: Tingidae), in Slovenia. Šumarski list 141(9-10): 485-488.

Mutun S. 2003: First report of the oak lace bug, Corythucha arcuata (Say, 1832) (Heteroptera: Tingidae) from Bolu, Turkey. Israel Journal of Zoology 49: 323-324. DOI: 10.1560/016e-u41t-h5kq-6f9u

Mutun S., Ceyhan Z., \& Sözen C. 2009: Invasion by the oak lace bug, Corythucha arcuata (Say) (Heteroptera: Tingidae), in Turkey. Turkish Journal of Zoology 33(3): 263-268. DOI: 10.3906/zoo-0806-13

Neimorovets V.V., Shchurov V.I., Bondarenko A.S., Skvortsov M.M. \& Konstantinov F.V. 2017: First Documented Outbreak and New Data on the Distribution of Corythucha arcuata (Say, 1832) (Hemiptera: Tingidae) in Russia. Acta Zoologica Bulgarica, Supplement 9: 139-142.

Poljaković-Pajnik L., Drekić M., Pilipović A., Nikolić N., Pap P., Vasić V. \& Marković M. 2015: Pojava velikih šteta od Corythucha arcuata (Say) (Heteroptera: Tingidae) u šumama hrasta u Vojvodini. XIII savetovanje o zaštiti bilja. Zbornik radova. str. 63.

Samin N. \& Linnavuori R.E. 2011: A contribution to the Tingidae (Heteroptera) from north and northwestern Iran. Entomofauna. Zeitschrift für Entomologie 32(25): 373-380.

Tuba K., Horváth B. \& Lakatos F. 2012: Inváziós rovarok fás növényeken. Nyugat-magyarországi Egyetem Kiadó, Sopron.

Érkezett: 2017. november 10.

Közlésre elfogadva: 2017. december 1. 